Comparative Philosophy Volume 6, No. 1 (2015): 80-90

Open Access / ISSN 2151-6014

www.comparativephilosophy.org

\title{
PERFORMATIVITY, SOCIAL ONTOLOGY, AND THE USES OF NARRATIVES IN LATIN AMERICA
}

\author{
IVAN MARQUEZ
}

\begin{abstract}
This article explains the relationship between performativity and social ontology in the case of Latin American narratives of resistance and liberation. In particular, it shows how these narratives construct social facts and provide social reality to experiences of oppression and to efforts of resistance and liberation, by means of performative functions tied to the creation and maintenance of social ontologies and to the struggle for identity, social recognition, sources of legitimacy, and hegemony. Latin America is not singular in the use of these kinds of narratives but it is special in the centrality that it gives to them and in its awareness of it. By way of example, the article touches upon four narratives that display some of these narrative features and functions: Elena Poniatowska's Massacre in Mexico (1975), Rigoberta Menchú's I, Rigoberta Menchú: An Indian Woman in Guatemala (1984), Domitila Barrios de Chungara's Let Me Speak!: Testimony of Domitila, a Woman of the Bolivian Mines (1978), and José Ignacio López Vigil's Rebel Radio: The Story of El Salvador's Radio Venceremos (1991).
\end{abstract}

Keywords: narrative, performativity, social ontology, consciousness-raising, testimonial, resistance, liberation, Latin America

\section{INTRODUCTION}

For the last 35 years, a segment of Anglo-American academic philosophy has shown an interest in the narrative medium as relevant to philosophy. The beginnings of this newfound interest could be traced back to Richard Rorty's post-analytic magnum opus, Philosophy and the Mirror of Nature (1979), which defended a move away from philosophy as epistemology towards philosophy as hermeneutics and argued that the hermeneutical task that deserved preeminence was the task of edification. Rorty's next book, Contingency, Irony, and Solidarity (1989), further defined this hermeneutical task as one of using narratives of cruelty to expand the circle of solidarity in liberal societies. During the same decade, Wayne C. Booth and Martha C. Nussbaum continued this interest in the edifying dimension of narratives by writing

MARQUEZ, IVAN: Assistant Professor, Department of Philosophy, Texas State University, USA. Email: imarquez@txstate.edu 
two important books, The Company We Keep: An Ethics of Fiction (1988) and Love's Knowledge:Essays on Philosophy and Literature (1990) respectively, which describe and argue for the ethical functions of literature in the construction of self and community. Meanwhile, philosophers such as Michel Foucault, Ian Hacking, Bruno Latour, and John Searle developed theoretical accounts of social ontology. ${ }^{1}$ Finally, social ontology was linked to speech act theory in the work on John Searle and Judith Butler and some of the political dimensions of these developments were articulated in the work of Michel Foucault, Judith Butler, Miranda Fricker, and Jose Medina among others. $^{2}$

In Latin America, narratives have traditionally occupied a place of importance both socially and culturally and since the 1970's narratives of resistance and liberation have been an integral part of processes of political, social, and cultural mobilization. Furthermore, decolonial critiques of Latin American history and development have examined narratives that have served as legitimation discourses in the processes of conquest, colonization, independence, nation building, and modernization in the region. ${ }^{3}$

This article will explain the uses of Latin American narratives of resistance and liberation from the point of view of performativity and social ontology. In particular, it will show how these narratives construct social facts and provide social reality to experiences of oppression and to efforts of resistance and liberation. Latin America is not singular in the use of these kinds of narratives but it is special in the centrality that it gives to them and in its awareness of it.

\section{NARRATIVE: PERFORMATIVITY AND SOCIAL ONTOLOGY}

From Bartolomé de las Casas's History of the Indies (1561/1971) and Garcilaso de la Vega's Royal Commentaries of the Incas (1609/1966) to Octavio Paz's Labyrinth of Solitude (1961) and Gabriel García Márquez's News of a Kidnapping (1996), Latin America has displayed a strong predilection for the narrative medium as transmission vehicle of social knowledge and format for analysis and synthesis. It should be noted that most prominent Latin American writers, Octavio Paz, Gabriel García Márquez, Isabel Allende, Elena Poniatowska, Carlos Fuentes, and Mario Vargas Llosa among others, started their careers as journalists and never ceased to write nonfiction narratives.

Latin America's predilection for the narrative medium has deep historical roots. Latin American culture is a composite of Native American, African, and Iberian cultures. The Native American and African cultures are traditional cultures that favor

\footnotetext{
1 See Foucault (1970, 1972); Hacking (1999); Latour (1987); Searle (1995).

${ }^{2}$ See Butler (1989, 1997); Foucault (1975); Fricker (2007); Medina (2013); Searle (1995).

${ }^{3}$ See Canclini (1989, 2001, 2014); Franco (2002); Greer, Mignolo and Quilligan (2007); Mignolo (1994, 2000, 2011); Pratt (1991); Rama (1996, 2012).

${ }^{4}$ For other theoretical accounts of the relationship between performativity and social ontology, see Barad (2003); Law and Urry (2005); Pels, Hetherington, and Vandenberghe (2002).
} 
the oral tradition of historical recording and knowledge transmission. ${ }^{5}$ This feature, coupled with the more European emphasis on the written word as historical and epistemological recording medium displayed by Iberian culture, engendered the narrative as the prime medium for Latin American intellectual production. Another source of Latin America's fondness for the narrative medium is the relative underdevelopment of its political structures, state apparatuses, and academic institutions. In a continent that exhibits these socio-political and cultural features, intellectual work tends to be done "on the side" and "while doing something else". This nonspecialized environment of knowledge production is linked to and, in itself, constructs and maintains nonspecialized fora of intellectual exchange. As a consequence, some of the foremost Latin American thinkers are public figures who contribute to the dialogue within the public sphere, while being "organically" integrated a la Gramsci into diverse sectors of social life that have little or nothing to do with research universities and specialized academic journals. ${ }^{6}$ This intellectual form of life is highly compatible with the narrative form of knowledge production and delivery.

I have briefly mentioned that the narrative medium exists in Latin America and why it exists. Now I want to explain how it exists - its functions and its functionings. From the beginning of the Spanish conquest of America, there has been an epistemological struggle for the privilege to tell the "official story" of the reality of Latin America. Bartolomé de las Casas' and Garcilaso de la Vega's narratives are pitted against the accounts of the officials of the Spanish Crown. And the pattern continues to this day. In Latin America, social realities do not acquire social existence simply by having happened. In the absence of epistemological validation from the hegemonic powers, many epistemological subjects lack the automatic legitimation grounds for their claims of social knowledge.

But the problems plaguing certain types of social knowledge do not end here. Social knowledge is not only threatened by the existence of structures of power that bestow differential levels of social existence upon social realities and of epistemological legitimation to epistemological subjects and their social knowledge. Throughout this past century, the Western world has put into question the very possibility of objective knowledge about social reality and the old certainties about the adequate forms for the content of that knowledge.

Friedrich Nietzsche's perspectivism ${ }^{7}$ has begotten postmodernist relativism. The positivist form/content distinction has given in to the social constructionists' formcontent mélange. These intellectual developments, together with the end of $19^{\text {th }}$ and $20^{\text {th }}$ century colonial imperialism, the spread of formal representative democracy, and the explosion of mass culture have further eroded the bases of epistemological, ethical, and aesthetic normativity. Epistemological, ethical, and aesthetic statuses have been democratized and given mobility in unprecedented ways and in ways that

\footnotetext{
${ }^{5}$ See Hill Boone and Mignolo (1994) for alternative literacies and media of knowledge transmission.

${ }^{6}$ See Gramsci (2011).

${ }^{7}$ See Nietzsche (1966).
} 
are not clearly defined. This is evident in the blurring of many binary distinctions that used to constitute received "natural kinds": high/low culture, adult/youth, educated/uneducated, rich/poor, White/Indian, European/native, civilization/ barbarism. It is as if the anticolonialism trend has been extended from the political realm into the social and cultural realms. Therefore, it seems that democracy has come to live with us with her cousin, relativism.

We live in a world where epistemological subject positions are constantly been contested, within and among individuals. With no common currency, the market place of ideas has lost its measure of value and social realities fight for social existence in an unequal distribution market.

Latin American narratives have internalized all of these tensions of the contemporary zeitgeist, reflecting on them while simultaneously displaying them. An awareness of the irreducibility of a certain degree of perspectivism at the phenomenological level and a measure of constructivism within the narrative medium has produced narratives that both reflect on and show this. The past 50 years of Latin American cultural production contains ample evidence of this.

Julio Cortázar's Hopscotch (1966) plays with the traditional regulative idea of the linearity of the narrative medium, by constructing a text that lacks a single "natural" sequencing, challenging the reader to engage in multiple narrative orderings of the text. Mario Vargas Llosa's The Time of the Hero (1966) creates a single narrative but one that totally disregards the arrow of time and the determinacy of the space-time continuum as ruling Kantian categories of consciousness as displayed in the narrative medium. Gabriel García Márquez's famous short story, Leaf Storm (1972), just like Luis Puenzo's movie, The Official Story (1985), explores not so much the ordering of the narrative medium per se but the epistemological claims of any narrative. Alternating between the points of view of three different people, while constructing a narrative that describes the burial of a prominent foreigner in a small Latin American town, García Márquez shows the irreducible complexities that come into play when one tries to tell a true account of a series of events and the truth about a man, thus, problematizing two basic questions: What happened here? Who was this man? Finally, in Cortázar's Último Round [Last Round] (1969), narratives are constructed using the formal techniques of pastiche, juxtaposing texts from various media in an attempt to capture the multiperspective richness resulting in taking into account and acknowledging the existence and validity of different points of view and of different media of expression and transmission.

Granting the validity of all that has been said so far, the fact is that sometimes, when language's referential functions are floated, its performative functions are in turn, intensified. Constative utterances give way to performative utterances and locutionary acts give way to illocutionary acts with illocutionary force and perlocutionary effects. ${ }^{8}$ This is certainly the case with Latin American narratives. In a

${ }^{8}$ See J. L. Austin, How to do Things with Words (1975) for the foundational text on speech act theory and Quentin Skinner's "Some problems in the analysis of political thought and action" (1974) and "Language and social change" (1980) for an effective application of speech act theory to the understanding of socio-political thought and discourse. For an extended account of the performative 
world of multiple contested readings of reality, marginalized epistemological subjects resort to telling their story as first-person testimonials. Testifying becomes a performative linguistic move bestowing a certain measure of social existence to the social reality experienced by that epistemologically marginalized subject. Primarily, it serves as self-referential validation of a subject's phenomenological state. By testifying, one names an experience and one makes it public rather than simply private. By making it public, one makes it real, by giving it a life of its own, both within a linguistic community and within a community of subjects who share a certain degree of intersubjectivity at the phenomenological level of lived experience. The fact that the testimonial makes a private phenomenological state of a specific subject public and gives the testimony itself a life of its own, helps to create a social currency for the transmission and exchange of an experience among different subjects, giving social existence to that experience and thus transforming it into social knowledge.

These performative effects of testimonials function to preserve and promote perspectives and to cognitively empower the bearers of them. Aspects of what Paulo Freire has labeled "consciousness-raising" (or in the original Portuguese form, conscientização) can only be achieved when experiences are first given a name and given birth into the public realm. ${ }^{9}$ This is the immanent, socio-linguistic version of the Gospel of John's transcendental, theological opening statement: "In the beginning there was the Word." Consciousness-raising partly consists of the act of making an experiential content real, by making it exist in your consciousness as referable, nameable content, and by creating a social communication form by means of which it can be transmitted to other people. Thus, under this guise, consciousness-raising consists of speech acts that simultaneously perform four functions: (1) name an experiential content that was previously unnamed, (2) give social existence to this content, (3) create the social communication form by means of which the content can be transmitted, and (4) constitute the intersubjective transmission itself.

Subjects who share the phenomenological experience of the subject who testifies participate in a feedback loop that clarifies and strengthens their own experiential reality, a reality that previously might have been not only socially invisible but invisible even to the subjects themselves. For subjects who do not share the same subject position as the subjects who testify, first-person narratives allow them to vicariously experience what the others have experienced first-hand and to the extent that this kind of indirect experiences has cognitive effects on the bearers of them, it represents additional effects of the speech acts that constitute acts of consciousnessraising.

The fundamental functional rationale of the first-person narrative is, thus, to directly empower marginalized subjects and to indirectly change the hegemonic subjects, making them more empathetic and thus more inclined to show solidarity

functions of discourse based on speech act theory, see Pratt (1997) and for a semiotics based account, see Mignolo (1978).

${ }^{9}$ See Freire (1973). 
toward subjects others than themselves. This empathy and solidarity leads some to become third-person narrators of that same reality, thus, performing the functions of "legitimator", "facilitator", and "communication bridge" or "messenger" that Latin Americans sometimes refer to by the notions of "bearing witness" and "interpellation". In fact, to the extent that any narration involves an act of mediation, any first-person narration is also in effect a third-person narration and vice versa and Latin America certainly has many exemplars of both narrative forms.

Narratives have at least one additional function. They can be seen as the locus of a kind of immanent, situated knowledge of social reality. Narratives, in this sense, can be defined in opposition to the kind of abstract, transcendent, theoretical knowledge that is disembodied from the irreducible particularity of social life. In this regard, the methodological claim of the narrative medium is that the metaphysical structure of the world and/or the epistemological limitations of human cognition force us to be low key and stay close to the ground, so to speak, when it comes to our attempts to produce knowledge of social reality. Narratives, thus, perform pedagogical and epistemological functions in the social sciences that are somewhat analogous to the ones played by the "case study" in the practical arts of medicine, jurisprudence, or business. Narratives help us to develop a direct cognitive access and a sensibility to situations of a certain kind, plus, a non-theoretical know how applicable to those situations.

This way of looking at narrative sometimes also involves a critique of the traditional separation between theory and action, substituting that separation by a dialectical relation between the two. In Latin America, the metaphysical and epistemological reality of the inseparability of thinking and acting is referred to by the philosophical term, praxis. Regardless of the ideological connotations of this term, as long as we stay at this level of generality in our characterization of the notion of praxis, Latin America's orientation toward praxis is analogous (but not homologous) to the American "pragmatic" bent (pragmatic as in "pragmatism" not as in "practicalmindedness").

I will briefly touch upon four narratives displaying some of the narrative features and having some of the functions noted above. First, Elena Poniatowska's Massacre in Mexico (1975), uses the techniques of pastiche to construct a multiperspective narrative of a famous 1968 student demonstration and its violent repression by the Mexican government. Poniatowska juxtaposes "texts" taken from newspapers, interviews, graffiti, government press conferences, radio commentaries, etc. to give a holistic account of these events. However, she refuses to produce a closed narrative, consistent and complete, in the axiomatic logico-mathematical meaning of these terms. Instead, the narrative as system remains open, inconsistent and incomplete, producing the journalistic narrative equivalent of Cinéma Vérité. In this way, Poniatowska produces a kaleidoscopic testimonial of the events while simultaneously leaving open questions of truth and responsibility.

Second, Nobel Peace Prize winner, Rigoberta Menchú's I, Rigoberta Menchú: An Indian Woman in Guatemala (1984), is the paradigmatic Latin American first-person narrative for many different reasons. First, it is a classic underdog story of the 
struggle of the Mayan poor against the forces of the rich, white minority in Guatemala. A narrative that seems to tap into our common source of basic human archetypical forms, thus, making it instantly and universally appealing. Secondly, it is a narrative coming from a marginalized subject, Rigoberta Menchú, who inhabits a Native American culture that favors the oral tradition. However, prompted by an hegemonic subject, Elisabeth Burgos-Debray, steeped in the European culture that favors the written word, allows herself to be recorded while telling "her story", and from those tapes emerges her testimony in writing, thus, making it "official". Third, the production of this narrative involves multiple mediations, not only the mediation of spoken language (parole), tape recording, and written language (langue), but also two languages, Menchú's native Quiché and her recently acquired, and thus rudimentary, Spanish, plus, Burgos-Debray's native and cultivated Spanish, and two nationalities, Menchú's Guatemalan and Burgos-Debray's Venezuelan, meeting in a third country, France. Fourth, we have the fact that a doubly marginalized subject: an Indian and a woman, teams up with a singly marginalized subject: a European but a woman, to produce a narrative that captures the imagination of many Western readers. Finally, there is the issue of the later accusations leveled against both Menchú and Burgos-Debray regarding alleged inaccuracies in the narrative account, concerning what happened and to whom it happened, bringing to the foreground the very same issues of objectivity and representation already mentioned, plus, obviously, the more basic and less philosophical issues of lying, victimizing, and ideological manipulation of and profiteering from "the truth". To add complexity to the dispute, one can come to the defense of this narrative by making distinctions between the "factual truth" and the "moral truth" of an account and between a particular and concrete example of a life and a general and universal exemplar of a life that is represented in a narrative.

Third, Domitila Barrios de Chungara's account of her participation in the International Women's Year Tribunal from her book, Let Me Speak!: Testimony of Domitila, a Woman of the Bolivian Mines (1978), stresses the difficulties of communicating and of creating a common ground for discussion and action in even a putatively homogeneous group like Latin American feminist women representatives. This account describes Barrios de Chungara's experience as a representative of poor Bolivian women activists to an International Women's Year Conference in Mexico in 1975. The narrative displays the lack of a common metanarrative to explain women's reality by showing how Latin American rich, educated, feminist women have trouble understanding Latin American poor, uneducated, feminist women as each group apparently inhabits a different subject position from which its narrative ensues. In an ironic moment in the narrative, the crypto-Marxist point emerges that, for better or for worse, not gender or sex but only poverty seems to create enough common existential currency to function as a hermeneutical bridge uniting poor women across otherwise real divisions of nationality, culture, and race, allowing for a significant level of mutual understanding and common ground for action among themselves.

Fourth, José Ignacio López Vigil's Rebel Radio: The Story of El Salvador's Radio Venceremos (1991), is a significant narrative because it shows how mass 
communication media, in this case, the radio, can be used as an organizing tool for a social and political movement.

Traditionally, orality has been subjected to strict limitations of space and time. Pure verbal utterance only transmits information within a short spatial range and its lifespan is restricted to the moment of enunciation. If the information is not transferred immediately to other media like memory or the written word, that particular information transmittal is forever lost. However, the invention of the radio allowed for a dramatic extension of the spatial range of speech. With the communication medium of radio, speech's distribution scope and range and thus its possible effects on other subjects were greatly multiplied. The medium of the written word has the advantage of permanence but it lacks the element of simultaneity of a radio broadcast. Only with the advent of email and the internet has the written word acquired something that approximates this quality of a radio broadcast. But in an economic and cultural context of poverty, technological backwardness, significant levels of illiteracy, and sometimes even multilingualism, nothing beats the amazing capabilities of the lo-fi radio as a mass media communication and organization tool. López Vigil's narrative explores in some detail the vast ramification of this phenomenon, by describing the role played by a pirate radio station in El Salvador's 12-year civil war (1980-1992) between an oligarchic government, the military and right-wing paramilitary groups, and the rural and urban FMLN ${ }^{10}$ guerrilla groups and their rural and urban supporters and sympathizers. In particular, his narrative shows how this pirate radio station aided in the creation of a collective consciousness of the revolution, unifying many social actors by means of its constant programing, helping to create a commonality of purpose, coordinating social action, and providing a unifying framework for the understanding of social reality of marginalized and progressive groups and of diverse communities, thus, ultimately acting as the head, eyes, ears, and voice of the insurgency movement.

\section{CONCLUSION}

Narratives are mostly seen as either vehicles of fiction or bearers of collective memory. Sometimes they are also seen as tools for a kind of sentimental education. This article has tried to expand this view of the uses and functions of narratives to include many more things and also to problematize and deepen these traditional uses and functions that have been given to it. It has tried to show that narratives have performative functions tied to the creation and maintenance of social ontologies and to the struggle for identity, social recognition, sources of legitimacy, and hegemony and the ways in which these are enacted. Although Latin America is not the only place where narratives play diverse functions, it is a place where society has put them to many uses and has placed great expectations upon them. This article has just hinted at a field that has much potential for further development and application, illuminating many social phenomena and philosophical issues.

\footnotetext{
${ }^{10}$ Frente Farabundo Martí para la Liberación Nacional.
} 


\section{ACKNOWLEDGEMENTS}

Thank you to anonymous referees of this journal for their evaluation and comments.

\section{REFERENCES}

Austin, John L. (1975), How to Do Things with Words (Cambridge: Harvard University Press).

Barad, Karen (2003), "Posthumanist Performativity: Toward an Understanding of How Matter Comes to Matter", Signs, 28 (3): 801-831.

Barrios de Chungara, Domitila (1978), Let Me Speak!: Testimony of Domitila, a Woman of the Bolivian Mines, trans. Moema Viezzer (New York: Monthly Review Press).

Booth, Wayne C. (1988), The Company We Keep: An Ethics of Fiction (Berkeley: University of California Press).

Butler, Judith (1989), Gender Trouble: Feminism and the Subversion of Identity (New York: Routledge)

- (1997), Excitable Speech: A Politics of the Performative (New York: Routledge).

Cortázar, Julio (1966), Hopscotch, trans. Gregory Rabassa (New York: Pantheon Books).

- (1969), Último Round (D.F., Mexico: Siglo XXI).

de la Vega, Garcilaso (1609/1966), Royal Commentaries of the Incas, trans. Harold Victor Livermore (Austin: University of Texas Press).

de las Casas, Bartolomé (1561/1971), History of the Indies, trans. Andrée Collard (New York: Harper \& Row).

Foucault, Michel (1970), The Order of Things: An Archaeology of the Human Sciences, (New York: Vintage Books).

- (1972), The Archaeology of Knowledge and the Discourse on Language (New York: Pantheon).

- (1975), Discipline and Punish: The Birth of Prison, trans. Alan Sheridan (London: Penguin).

Franco, Jean (2002), The Decline and Fall of the Lettered City: Latin America in the Cold War (Cambridge: Harvard University Press).

Freire, Paulo (1973), Education for Critical Consciousness, trans. Myra Bergman Ramos (New York: Continuum).

Fricker, Miranda (2007), Epistemic Injustice: Power and the Ethics of Knowing (Oxford: Oxford University Press).

García Canclini, Nestor (1989), Hybrid Cultures: Strategies for Entering and Leaving Modernity, trans. Christopher L. Chiappari and Silvia L. Lopez (Minneapolis: University of Minnesota Press).

- (2001), Consumers and Citizens: Globalization and Multicultural Conflicts, trans. George Yudice (Minneapolis: University of Minnesota Press). 
- (2014), The Imagined Globalization, trans. George Yudice (Durham: Duke University Press).

García Márquez, Gabriel (1972), Leaf Storm, trans. Gregory Rabassa (London: Penguin).

- (1996), News of a Kidnapping, trans. Edith Grossman (New York: Penguin).

Gramsci, Antonio (2011), The Prison Notebooks, trans. Joseph A. Buttigieg (New York: Columbia University Press).

Greer, Margaret R., Mignolo, Walter D. and Quilligan, Maureen (eds) (2007), Rereading the Black Legend: The Discourses of Religious and Racial Difference in the Renaissance Empires (Chicago: University of Chicago Press).

Hacking, Ian (1999), The Social Construction of What? (Cambridge: Harvard University Press).

Hill Boone, Elizabeth and Mignolo, Walter D. (eds) (1994), Writing Without Words: Alternative Literacies in Mesoamerica and the Andes (Durham: Duke University Press).

Latour, Bruno (1987), Science in Action: How to Follow Scientists and Engineers through Society (Cambridge: Harvard University Press).

Law, John and Urry, John (2004), "Enacting the Social", Economy and Society, 33 (3): 390-410.

López Vigil, José I. (1991), Rebel Radio: The Story of El Salvador's Radio Venceremos, trans. Mark Fried (Willimatic, Connecticut: Curbstone).

Medina, José (2013), The Epistemology of Resistance: Gender and Racial Oppression, Epistemic Injustice, and Resistant Imaginations (New York: Oxford University Press).

Menchú, Rigoberta and Burgos-Debray, Elisabeth (1984), I, Rigoberta Menchú: An Indian Woman in Guatemala, trans. Ann Wright (London: Verso).

Mignolo, Walter D. (1978), Elementos para una Teoría del Texto Literario (Barcelona: Editorial Crítica).

- (1994), The Darker Side of the Renaissance: Literacy, Territoriality, and Colonization (Ann Arbor: University of Michigan Press).

- (2000), Local Histories/Global Designs: Coloniality, Subaltern Knowledges, and Border Thinking (Princeton: Princeton University Press).

- (2011), The Darker Side of Western Modernity: Global Futures, Decolonial Options (Durham: Duke University Press).

Nietzsche, Friedrich W. (1966), Beyond Good and Evil: Prelude to a Philosophy of the Future, trans. Walter Kaufmann (New York: Vintage Books).

Nussbaum, Martha C. (1990), Love's Knowledge: Essays on Philosophy and Literature (Oxford: Oxford University Press).

Paz, Octavio (1961), The Labyrinth of Solitude: Life and Thought in Mexico, trans. Lysander Kemp (New York: Grove Press).

Pels, Dick, Hetherington, Kevin, and Vandenberghe, Frédérick (2002), "The Status of the Object: Performances, Mediations, and Techniques", Theory, Culture \& Society, 19 (1): 1-21. 
Poniatowska, Elena (1975), Massacre in Mexico, trans. Helen R. Lane (New York: Viking Press).

Pratt, Mary L. (1977), Toward a Speech Act Theory of Literary Discourse (Bloomington: Indiana University Press).

- (1991), Imperial Eyes: Travel Writing and Transculturation (London: Routledge). Puenzo, Luis (1985), The Official Story (Beverly Hills: Pacific Arts Video).

Rama, Angel (1996), The Lettered City, trans. John Charles Chasteen (Durham: Duke University Press).

- (2012), Writing Across Cultures: Narrative Transculturation in Latin America, trans. David L. Frye (Durham: Duke University Press).

Rorty, Richard (1979), Philosophy and the Mirror of Nature (Princeton: Princeton University Press).

- (1989), Contingency, Irony, and Solidarity (Cambridge: Cambridge University Press).

Searle, John R. (1995), The Construction of Social Reality (London: Penguin).

Skinner, Quentin (1974), "Some Problems in the Analysis of Political Thought and Action", Political Theory, 2 (3): 277-303.

- (1980), "Language and Social Change", in Micheals, L. and Ricks, C. (eds), The State of the Language (Berkeley: University of California Press), 562-578.

Vargas Llosa, Mario (1966), The Time of the Hero, trans. Lysander Kemp (New York: Harper \& Row). 